\title{
Physiological measurements on Nucula tenuis and on isolated gills of Mytilus edulis and Carcinus maenas
}

\author{
B. L. Bayne ${ }^{1}$, F. P. Thurberg ${ }^{2}$ \\ ${ }^{1}$ Plymouth Marine Laboratory (West Hoe), Prospect Place, The Hoe, Plymouth PL1 3DH, United Kingdom \\ ${ }^{2}$ National Marine Fisheries Service, NOAA, Northeast Fisheries Centre, Milford Laboratory, Milford, Connecticut 06460, USA
}

\begin{abstract}
In experimental exposures carried out for the GEEP Workshop, measurements on the deposit-feeding bivalve mollusc Nucula tenuis indicated an increase in protein catabolism in the medium and low-dose mesocosm basins, registered as increased nitrogen quotients; the implications for pollutant effect assessment are unclear, but further research on deposit-feeding species is warranted. For Mytilus edulis, gill oxygen uptake rates did not differ between samples, in either the workshop field or mesocosm studies; oxygen consumption rates of isolated gills correlated with consumption rates for the whole organism, but showed no relationship with clearance rate. Rates of oxygen consumption by isolated gills of Carcinus maenas revealed effects of pollution at one of the field sites, but were unresponsive to contaminant levels within the mesocosm. In these experiments, measures of physiological function in isolated tissues were relatively insensitive to pollutant stress.
\end{abstract}

\section{INTRODUCTION}

Mytilus edulis is a suspension-feeding bivalve; it lives attached to the substratum and is vulnerable to contaminants which are dissolved or in colloidal form in the water column, and to contaminants associated with suspended sediments. The deposit-feeding bivalve Nucula tenuis, on the other hand, lives within the sediments and is presumed to be exposed primarily to contaminants within the pore-waters of the sediment or those associated with the sediment particles themselves. Carcinus maenas, a widely distributed crustacean, inhabits coastal and estuarine habitats on both sides of the North Atlantic; it is predominantly carnivorous and tolerant of a wide range of environmental stresses.

Many responses by marine invertebrates to contamination involve increased protein synthesis and an increase in the processes of cell repair and tissue maintenance. Examples for Mytilus edulis include the de novo synthesis of metal-binding proteins (George \& Viarengo 1986); enhanced protein catabolism following damage to lysosomal membranes (Moore \& Viarengo 1987 ), requiring extra synthesis to maintain pro- tein balance; and compensation for cell depletion as a result of toxic action (Pipe \& Moore 1986). On a priori grounds therefore, it is likely that exposure to contaminants will disturb protein balance, and their effects therefore be detectable in measures of protein catabolism and nitrogen excretion. Aspects of these processes were measured on $N$. tenuis from the Solbergstrand mesocosms as a preliminary effort to describe responses to contaminants by a deposit-feeding bivalve (see Widdows \& Johnson 1988, for similar measurements on M. edulis).

The possibility of using isolated tissues of organisms which have experienced environmental contamination as monitors of biological effects is appealing for many reasons. Much of the variability in rates of oxygen consumption by intact whole organisms is due to behavioural differences between individuals that cannot readily be controlled by the experimenter. This variability may be reduced if isolated tissues, not subject to central neuronal control, could be shown to reflect the contaminant history of the organisms when measured under standard conditions in the laboratory. Respiration rates are known to be sensitive to conta- 
minants in a variety of species (Thurberg et al. 1973, Calabrese et al. 1977, Bayne et al. 1980).

In this contribution to the GEEP Workshop, rates of oxygen consumption of isolated gills from mussels and crabs, taken both from the field sites and mesocosm basins, were measured to evaluate their possible role in biological effects assessments. The degree of coherence between oxygen consumption rates by isolated mussel gills and paired measurements on whole organisms was also examined.

\section{MATERIAL AND METHODS}

Nucula tenuis were collected from the outer Oslofjord, and 35 individuals were added to undisturbed box-cores of sediments within each of the Solbergstrand mesocosm basins on 15 May 1986, as described by Bakke et al. (1988). The box-cores were removed from the basins on 15 August and sieved for recovery of the clams. No $N$. tenuis were recovered from the highdose basin (the identity of the basins was not known at the time of sampling, in accordance with the basic protocol of the workshop). Specimens from the other 3 basins were kept in water from the appropriate exposures $\left(10^{\circ} \mathrm{C}\right)$ and transported to Oslo for measurements of oxygen consumption and ammonia-nitrogen excretion rates over the following $2 \mathrm{~d}$.

Eight Nucula tenuis were placed individually in small Gilson flasks with $10 \mathrm{ml}$ of water from the appropriate basin; the water had previously been filtered through $0.45 \mu \mathrm{m}$ membrane filters and stored overnight at $10^{\circ} \mathrm{C}$. The Gilson respirometer was equilibrated at $10^{\circ} \mathrm{C}$, and rates of oxygen consumption measured over $3 \mathrm{~h}$. The clams were then removed and placed immediately in $9 \mathrm{ml}$ of filtered seawater, also from the appropriate basin and also at $10^{\circ} \mathrm{C}$. After $6 \mathrm{~h}$ incubation, the clams were removed and the medium analysed for ammonia-nitrogen using the method described by Grasshoff \& Johannsen (1972). Control ammonia concentrations, determined on water incubated without animals, were subtracted from the concentrations in the medium with clams, and rates of ammonia-nitrogen excretion per hour calculated.

The clam tissue was then dissected from each shell and oven-dried at $85^{\circ} \mathrm{C}$ to constant weight. Although individual Nucula tenuis were selected to be of similar shell length, they differed in dry tissue weight. Physiological rates were therefore standardised to $10 \mathrm{mg}$ dry flesh weight using the expression

$$
X_{\text {stan }}=(10 / W)^{b} X_{\text {meas }}
$$

where $X_{\text {stan }}=$ standardised rate; $X_{\text {meas }}=$ measured rate (oxygen consumption or ammonia-nitrogen excretion); $W=$ measured flesh dry weight $b=$ the exponent which describes the allometry between rate and tissue dry mass (see 'Results').

The Oxygen:Nitrogen ratio was calculated for each individual, as atomic equivalents, according to Bayne et al. (1985), and the Nitrogen Quotient calculated according to Gnaiger (1983). These ratios are used to assess the utilisation of protein as a respiratory substrate. In such an analysis the assumption is made that rates of protein turnover are expressed in rates of nitrogen excretion, though this assumption may not hold in all circumstances (see Discussion). In this study the hypothesis employed (see Introduction) states that increased protein catabolism, and an increased reliance on protein as respiratory substrate, are causally related to contaminant exposure.

Mytilus edulis were taken from the field and mesocosm collections as they were delivered to the laboratory (Bakke et al. 1988, Follum \& Moe 1988). Gills were immediately dissected from 9 individuals, washed in membrane-filtered seawater and placed in $10 \mathrm{ml}$ of clean, filtered water in Gilson respirometer flasks. Rates of oxygen consumption were determined over $3 \mathrm{~h}$ at $10^{\circ} \mathrm{C}$. Gill tissue was then rinsed in distilled water and dried overnight at $85^{\circ} \mathrm{C}$, prior to weighing. Calculated oxygen consumption rates were standardised to $40 \mathrm{mg}$ dry tissue weight as described above. This procedure was followed for all field sites and for control (C), low (L) and medium (M) dose basins (without, at the time, knowing the sample designations). For the high $(\mathrm{H})$ dose basin, however, only 6 mussels were available (Widdows \& Johnson 1988) and these individuals were not sampled 'blind'.

In addition, 18 mussels were transported from Solbergstrand to Oslo within $10 \mathrm{~d}$ of their having been used in whole-animal determinations of oxygen consumption and filtration rates (Widdows \& Johnson 1988). This sample consisted of a mixture of individuals from the $C$, $I$ and $M$ basins (6 from each, though designations were again unknown). Gills were dissected as described above, incubated for $3 \mathrm{~h}$ in the Gilson respirometer for determination of oxygen consumption rates, and then dried and weighed. The measured rates were compared with rates recorded by Widdows \& Johnson for oxygen consumption and filtration, in order to assess any coherence between results on isolated gill tissue and on the whole organism.

Carcinus maenas were collected daily from the field sites and mesocosm basins. Gill tissues from one side of each crab were then removed and placed in Gilson respirometer flasks together with $5 \mathrm{ml}$ of clean seawater of the same salinity as the collection site. Rates of oxygen consumption were measured over $3 \mathrm{~h}$ at $15^{\circ} \mathrm{C}$ and calculated as $\mu \mathrm{O} \mathrm{O}_{2}$ consumed $\mathrm{h}^{-1}$ per $10 \mathrm{mg}$ dry tissue weight, using the formula for weight standardisation given above. 
Table 1. Nucula tenuis. Rates of oxygen consumption $\left(\mu \mathrm{l} \mathrm{O}_{2} \mathrm{~h}^{-1}\right)$ and ammonia-nitrogen excretion $\left(\mu \mathrm{g} \mathrm{NH} \mathrm{N}_{4}-\mathrm{N} \mathrm{h}^{-1}\right)$, equivalent Oxygen: Nitrogen ratios $(O: N)$ and Nitrogen Quotients (NQ) for individuals from control (C), low (L) and medium (M) dose Solbergstrand basins. Means $\pm \mathrm{SD}, n=8$, standardised to a dry flesh weight of $10 \mathrm{mg}$

\begin{tabular}{crrrr|}
\hline Basin & Oxygen & Ammonia-N & O:N & NQ \\
\hline C & $5.23 \pm 1.41$ & $0.061 \pm 0.015$ & $113.9 \pm 34.7$ & $0.020 \pm 0.008$ \\
L & $4.12 \pm 0.43$ & $0.112 \pm 0.030$ & $49.9 \pm 17.0$ & $0.044 \pm 0.014$ \\
M & $7.07 \pm 1.62$ & $0.180 \pm 0.046$ & $52.3 \pm 18.2$ & $0.042 \pm 0.013$ \\
\hline
\end{tabular}

\section{RESULTS}

Rates of oxygen consumption and ammonia-nitrogen excretion by Nucula tenuis

No live Nucula tenuis were recovered from the $\mathrm{H}$ basin. Mean dry flesh weights in $\mathrm{mg}$ ( $\pm \mathrm{SD}, n=8$ ) for individuals from each of the other basins were as follows, C: 12.3 ( \pm 3.7 ), L: $15.4( \pm 6.5), \mathrm{M}: 8.1$ ( \pm 2.3 ).

Rates of oxygen consumption and ammonia-nitrogen excretion were standardised to a dry flesh weight of 10 $\mathrm{mg}$, using exponent values $\mathrm{b}=0.65$ for oxygen consumption and $b=1.19$ for nitrogen excretion (O. A. Follum pers. comm.). In the ANOVA of these standardised results (Table 1$)$ there was significant $(p<0.01)$ among-treatment variance for oxygen consumption, nitrogen excretion and $\mathrm{O}: \mathrm{N}$ ratio the latter after logarithmic transformation). Results of $t$-tests (ail on 14 df) between pairs of treatments were as follows. For rates of oxygen consumption, no difference between control and low dose basins ( $t=1.61$, ns), a significant difference between control and medium dose basins $(t$ $=2.70, p<0.05$ ), and a highly significant difference between low and medium dose basins $(t=4.32, p$ $<0.01$ ). For rates of ammonia-nitrogen excretion, all 3 comparisons were highly significant at $p<0.01$ ( $t=$ $3.07,7.17,4.10$ for the comparisons, respectively, between $\mathrm{C}-\mathrm{L}, \mathrm{C}-\mathrm{M}$ and $\mathrm{L}-\mathrm{M}$ basins). Comparing O:N ratios, Nucula tenuis from the control basin showed higher values than those from either low dose $(t=4.70, p<0.01)$ or medium dose $(t=4.43, p<0.01)$ basins, but there was no significant difference between low and medium dose treatments $(t=0.26$, ns).

Table 2. Nucula tenuis. Calculated mass fractions of protein $\left(W_{\mathrm{p}}\right)$, lipid $\left(W_{1}\right)$ and carbohydrate $\left(W_{\mathrm{k}}\right)$ catabolised by $N$. tenuis in the control $(\mathrm{C})$, low (L) and medium (M) dose Solbergstrand basins, based on observed Nitrogen Quotients and an assumed Respiratory Quotient of 0.8 (see text)

\begin{tabular}{|cccc|}
\hline Basin & $W_{\mathrm{p}}$ & $W_{1}$ & $W_{\mathrm{k}}$ \\
\hline $\mathrm{C}$ & 0.105 & 0.510 & 0.385 \\
$\mathrm{~L}$ & 0.236 & 0.513 & 0.251 \\
$\mathrm{M}$ & 0.225 & 0.513 & 0.262 \\
\hline
\end{tabular}

Following Gnaiger (1983), O:N ratios were converted to Nitrogen Quotients $(\mathrm{NQ}=2 / \mathrm{O}: \mathrm{N})$ and, assuming a Respiratory Quotient (RQ) of 0.8 , the mass fractions of protein $\left(W_{\mathrm{p}}\right)$ and carbohydrate $\left(W_{\mathrm{k}}\right)$ as respiratory substrates estimated (Table 2). Because of having to assume an $R Q$ value, these mass fraction estimates are only indicative of the scale of difference between treatments; with this caveat in mind, Nucula tenuis in both low and medium dose basins doubled their utilisation of protein as a respiratory substrate, relative to individuals in the control basin.

\section{Rates of oxygen consumption by isolated gills of Mytilus edulis}

Mean dry weights in $\mathrm{mg}$ ( $\pm \mathrm{SD}$ ) of gill tissue used in these determinations were, for field samples: 34.6 ( \pm 13.4, $n=20)$; for mesocosm samples: $44.6( \pm 11.4, n=$ 28). Measured rates of oxygen consumption were standardised in all cases to a dry tissue mass of $40 \mathrm{mg}$, which was established as an acceptable estimate of the weight of gill tissue in mussels of $1 \mathrm{~g}$ total dry flesh weight. In neither field or mesocosm data were there significant differences between samples as analysed by ANOVA on untransformed data (field samples: $F=$ 0.96 on $3,16 \mathrm{df}, \mathrm{ns}$; mesocosm treatments: $F=1.16$ on 3,24 df, ns).

\section{Comparison between rates of oxygen consumption of isolated gills and respiration and clearance rates of intact Mytilus edulis}

A total of 18 paired determinations of rates of oxygen consumption of intact Mytilus edulis, their rates of clearance of particles from suspension, and rates of oxygen consumption by isolated gills were made on the same individuals (Fig. 1a,b). There was a significant positive correlation between gill (standardised to $40 \mathrm{mg}$ of dry tissue) and whole-animal (standardised to $1 \mathrm{~g}$ dry tissue weight) oxygen consumption rates $(r=0.67, n=$ 18, $p<0.01$ ), but no significant relationship between gill oxygen consumption rates and whole-animal clearance rates $(r=0.26, n=18, n s)$ 


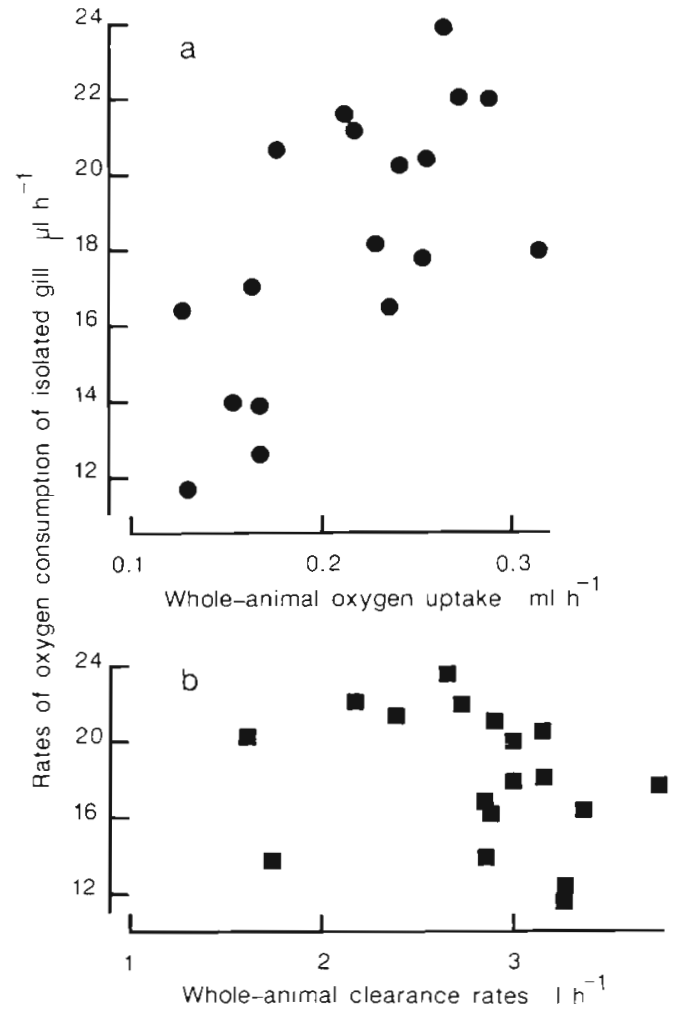

Fig. 1. Mytilus edulis. (a) Rates of oxygen consumption by isolated gill tissue ( $\mu \mathrm{O}_{2} \mathrm{~h}^{-1}$, standardised to a dry tissue weight of $40 \mathrm{mg}$ ), measured for 18 individuals, plotted against rates of oxygen consumption by the same individuals when intact ( $\mathrm{ml}$ $\mathrm{O}_{2} \mathrm{~h}^{-1}$, standardised to a dry tissue weight of $1 \mathrm{~g}$ ). (b) Rates of oxygen consumption by isolated gill tissues, as in (a), plotted against measures of rates of clearance $\left(\mathrm{l} \mathrm{h}^{-1}\right.$ standardised to a $\mathrm{dry}$ tissue weight of $1 \mathrm{~g}$ ) made for the same intact individuals

\section{Rates of oxygen consumption by isolated gill tissue of Carcinus maenas}

The dry weights of the Carcinus maenas gill tissue varied between 8 and $25 \mathrm{mg}$, with significant differences between samples. All oxygen consumption values were therefore weight-corrected to $10 \mathrm{mg}$ and analysed by ANOVA (Table 3). Measurements for Field sites 3 and 4 were significantly higher than for other sites. In the mesocosm basins, weight-corrected rates of gill tissue respiration from crabs exposed to contaminants were not significantly different from control values.

\section{DISCUSSION}

\section{Nucula tenuis}

Nucula tenuis is an in-faunal, deposit-feeding bivalve (Purchon 1968); ciliary currents on the enlarged labial palps collect and sort material from within the
Table 3. Carcinus maenas. Rates of oxygen consumption, $\mu \mathrm{I}_{2}$ $\mathrm{h}^{-1}(10 \mathrm{mg} \text { dry } \mathrm{wt})^{-1}$, by the gill tissue of crabs from the field sites and mesocosm basins (mean $\pm \mathrm{SD}, n=8$ ). Significant difference from the field reference site (1) indicated by $\cdot p<0.05$

\begin{tabular}{|cc|}
\hline Source & Rate of oxygen uptake \\
\hline Site & \\
1 & $10.4 \pm 1.5$ \\
2 & $11.0 \pm 2.4$ \\
3 & $20.3 \pm 2.1^{\circ}$ \\
4 & $14.2 \pm 2.6^{\circ}$ \\
Basin & \\
C & $8.6 \pm 1.5$ \\
L & $9.9 \pm 2.8$ \\
M & $9.2 \pm 1.7$ \\
H & $10.4 \pm 1.9$ \\
\hline
\end{tabular}

sediments, and carry the particles forward to the mouth. The species, which is common in the sediment communities within the Oslofjord (Valderhaug \& Gray 1984), was chosen for this study because it was presumed to be vulnerable primarily to contaminants within the sediments, in comparison to Mytilus edulis, which is an epifaunal suspension-feeder, exposed largely to water-borne contaminants. Physiological measurements on $N$. tenuis were confined to rates of oxygen consumption and ammonia-nitrogen excretion because a simple, standard procedure for determining rates of feeding that realistically reflects rates under natural circumstances was not available.

The absence of any specimens in the high-dose basin is presumably due to mortality during exposure over the 3 mo from 15 May to 15 August, since 35 specimens had been added to each sediment box. The causes of this mortality are unknown. For the remaining 3 basins, there were no detectable differences, within the sediments, in the concentrations of copper or other metals (Abdullah \& Steffenak 1988). Concentrations of selected aromatic hydrocarbons within sediments were more variable (Klungsøyr et al. 1988) but there were also no statistically significant differences between basins.

Differences in the physiological determinations on Nucula tenuis did not therefore reflect, in any consistent way, sediment contaminant levels. Individuals from the control basin had lower rates of nitrogen excretion and lower NQ (i.e. a smaller contribution by protein to the respiratory substrate) than those from either of the contaminated basins; differences between low and medium dose basins were less, and were non-existent as regards the Nitrogen Quotient. To the extent that the predicted response to contamination was an increase in $N Q$, these differences are broadly in line with observed levels of both copper and hydrocarbons within the water column, but such an interpretation begs the 
question of the exposure route to $N$. tenuis which, despite a deposit-feeding habit, may still be vulnerable to contaminants in the dissolved phase.

Measurements such as these provide a partial picture only of the status of nitrogen (protein) metabolism in the animal. A fuller analysis is only possible when protein turnover is determined using, for example, the stable isotope of nitrogen. These procedures are not yet available for routine use. The present study was intended to be preliminary and causation between contaminant levels and nitrogen metabolism can be considered tentative only. The other possible causes of an increased Nitrogen Quotient are reduced salinity (not a feature of this experiment) and shortage of food in the oil-treated basins $s_{i}$ there are no measures available of organic content of the mesocosm sediments, but counts by Schwinghamer (1988) did not indicate any marked differences in bacterial or benthic diatom abundance, suggesting that potential ration levels for Nucula tenuis would not have differed significantly between basins.

The results suggest that physiological differences between individuals of this deposit-feeder are detectable and that further investigations might be rewarded. It is certainly important that in-faunal species be studied in greater detail to act as potential monitors of the effects of sediment (and/or pore-water) contamination, to serve alongside the more thorough investigations of suspension feeding species.

Widdows \& Johnson (1988) report results with one such suspension-feeding species, Mytilus edulis. Rates of ammonia excretion and the Nitrogen Quotient were all similar amongst mussels from control, low and medium dose basins. With a similar assumption to that made here (i.e. $R Q=0.8$ ), the $N Q$ values for $M$. edulis from the control basin are equivalent to a contribution by protein of ca $50 \%$ of the respiratory substrate, which is 4 times greater than estimated for Nucula tenuis from the same basin. Rates of nitrogen metabolism are known to be very variable seasonally in this species (Bayne \& Scullard 1977). It may be that, when rates of protein catabolism are naturally high, enhanced demands on protein turnover are met by increasing the re-cycling of amino acids for protein synthesis (Hawkins et al. 1986). In these circumstances there would be no net change in the rate of ammonianitrogen excretion, and little change in the Nitrogen Quotient.

\section{Mytilus edulis}

It is of some interest to establish whether rates of oxygen consumption by isolated tissues of organisms, incubated under standard conditions, can be used to measure the effects of pollutants. If this were possible, much of the variability inherent in oxygen consumption by intact animals, particularly due to differences in level of activity, might be removed, providing a more sensitive measure of metabolic response. Thurberg et al. (1973) observed rates of oxygen consumption by isolated gills of some crustaceans which varied in accordance with the history of the animals' exposure to certain contaminants. For Mytilus edulis in this study, however, no such differences were observed.

Isolated gill tissue from Mytilus edulis continues to exhibit ciliary activity and to express a high rate of oxygen consumption. The respiration of this tissue represents a significant component of the respiration rate of the whole, intact, organism (ca $10 \%$, see Fig. 2a); not unexpectedly, the 2 rates correlate closely. Isolated gill tissue is not, however, expected to replicate the filtration function of the intact ctenidium. Since the responses of intact mussels to contaminants in the basins were detected primarily as reduced clearance rates (Widdows \& Johnson 1988), the intact gill preparation does not offer a surrogate for whole-animal studies to assess the effects of the contaminants in the environment.

\section{Carcinus maenas}

Rates of oxygen consumption by isolated gills from Carcinus maenas in the field reflect higher concentrations of aromatic hydrocarbons in crab tissues from Site 3 ; this correlation was particularly evident as far as naphthalene and its alkyl derivatives were concerned (Appendix 1, Table 5). These findings also tally with evidence (Capuzzo \& Leavitt 1988) of altered lipid metabolism in crabs from site 3 and with elevated glutathione transferase activity (Lee 1988), suggesting a link with enhanced detoxication activity.

In the mesocosm experiment concentrations of smallmolecular-weight hydrocarbons increased within crab tissues according to dose, reaching high levels in the high-dose basin (these levels were considerably higher than concentrations observed in crabs from the field), but there was no evidence of enhanced gill respiration in these crabs, nor was there evidence of altered lipid metabolism or detoxication activity (Capuzzo \& Leavitt 1988, Lee 1988). The exposure time for these crabs may have been insufficient to result in toxic effects measurable as increased gill respiration. In addition, the crabs in the mesocosm basins were all at inter-moult, unlike the crabs sampled from the field. Differential sensitivity during the moulting cycle may explain, in part, the results of our oxygen consumption determinations. The factors linking tissue respiration rates to processes of hydrocarbon turnover and to moulting in Carcinus maenas would benefit from further research. 


\section{LITERATURE CITED}

Abdullah, M. I., Steffenak, I. (1988). The GEEP Workshop: trace metal analyses. Mar. Ecol. Prog. Ser. 46: 27-30

Bakke, T., Follum, O. A., Moe, K. A., Sorensen, K. (1988). The GEEP Workshop: mesocosm exposures. Mar. Ecol. Prog. Ser. 46: 13-18

Bayne, B. L., Scullard, L. (1977). Rates of nitrogen excretion by species of Mytilus (Bivalvia: Mollusca). J. mar biol. Ass. U.K. 57 : $355-369$

Bayne, B. L., Anderson, J., Engel, D., Gilfillan, E., Hoss, D. Lloyd, R., Thurberg, F. P. (1980). Physiological techniques for measuring the biological effects of pollution at sea. Rapp. P.-v. Réun. Cons. int. Explor. Mer 179: 88-99

Bayne, B. L., Brown, D. A., Burns, K., Dixon, D. R., Ivanovici, A., Livingstone, D. R., Lowe, D. M., Moore, M. N., Stebbing, A. R. D., Widdows, J. (1985). The effects of stress and pollution on marine animals. Praeger Publishers, New York

Calabrese, A., Thurberg, F. P., Gould, E. (1977). Effects of cadmium, mercury and silver on marine animals. Mar Fish. Rev. 39: 5-11

Capuzzo, J. M., Leavitt, D. F. (1988). Lipid composition of the digestive glands of Mytilus edulis and Carcinus maenas in response to pollutant gradients. Mar. Ecol. Prog. Ser. 46: $139-145$

Follum, O. A., Moe, K. A. (1988). The GEEP Workshop: field sampling. Mar. Ecol. Prog. Ser. 46: 7-12

George, S. G., Viarengo, A. (1985). A model for heavy metal homeostasis and detoxication in mussels. In: Vernberg, F. J., Thurberg, F. P., Calabrese, A., Vernberg, W. (eds.) Marine pollution and physiology: recent advances. University of South Carolina Press, Columbia, S.C., p. 125-143

Gnaiger, E. (1983). Calculation of energetic and biochemical equivalents of respiratory consumption. In: Gnaiger, E., Forstner, H. (eds.) Polarographic oxygen sensors. Springer-Verlag. Berlin, Appendix C, p. 337-345
Grasshoff, K., Johannsen, H. (1972). A new, sensitive and direct method for the automatic determination of ammonia in seawater. J. Cons. int. Explor. Mer 34: 516-521

Hawkins, A. J. S., Bayne, B. L., Day, A. J. (1986). Protein turnover, physiological energetics and heterozygosity in the blue mussel Mytilus edulis: the basis of variable agespecific growth. Proc. R. Soc. Lond. B 229: 161-176

Klungsøyr, J., Wilhelmsen, S., Westrheim, K., Saetvedt, E., Palmork, K. H. (1988). The GEEP Workshop: organic chemical analyses. Mar Ecol. Prog. Ser. 46: 19-26

Lee, R. F. (1988). Glutathione S-transferase in marine invertebrates from Langesundfjord Mar. Ecol. Prog. Ser. 46: 33-36

Moore, M. N., Viarengo, A. (1987). Lysosomal membrane fragility and catabolism of cytosolic proteins: evidence for a direct relationship. Experientia 43: $320-323$

Pipe, R. K., Moore, M. N. (1986). Arylsulphatase activity associated with phenanthrene induced digestive cell deletion in the marine mussel Mytilus edulis. Histochem. J. 18: $557-564$

Purchon, R. D. (1968). The biology of the Mollusca. Pergamon Press, Oxford

Schwinghamer, P. (1988). Influence of pollution along a natural gradient and in a mesocosm experiment on sediment microbial numbers and biomass. Mar. Ecol. Prog. Ser. 46: 193-197

Thurberg, F. P., Dawson, M. A., Collier, R. S. (1973). Effects of copper and cadmium on osmoregulation and oxygen consumption in two species of estuarine crabs. Mar Biol. 23: $171-175$

Valderhaug, V. A., Gray, J. S. (1984). Stable macrofauna community structure despite fluctuating food supply in subtidal soft sediments in Oslofjorden, Norway. Mar. Biol. 82: $307-322$

Widdows, J, Johnson, D. (1988). Physiological energetics of Mytilus edulis: Scope for Growth. Mar. Ecol. Prog. Ser. 46: $113-121$ 